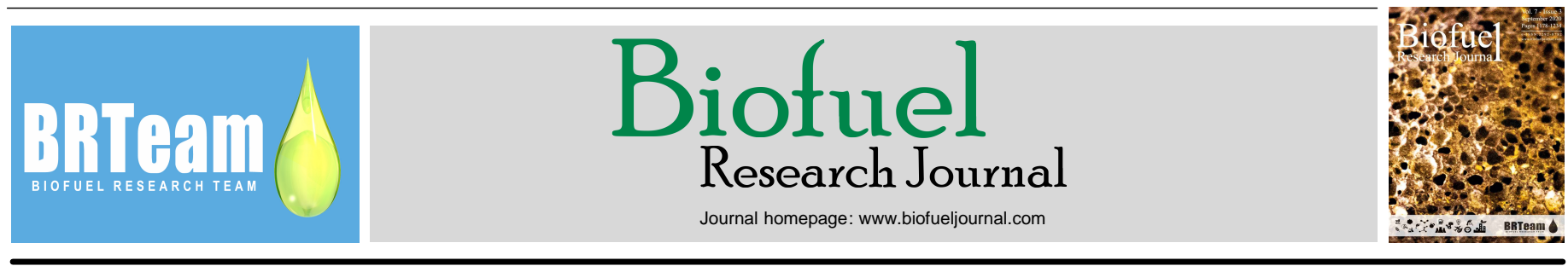

Original Research Paper

\title{
Sustainable carbon capture via halophilic and alkaliphilic cyanobacteria: the role of light and bicarbonate
}

\author{
Wenfan $\mathrm{Ye}^{1,2}$, Ao Xia ${ }^{1,2, *}$, Cheng Chen ${ }^{1,2}$, Qiang Liao ${ }^{1,2}$, Yun Huang ${ }^{1,2}$, Xianqing Zhu ${ }^{1,2}$, Xun Zhu ${ }^{1,2}$ \\ ${ }^{1}$ Key Laboratory of Low-grade Energy Utilization Technologies and Systems, Chongqing University, Ministry of Education, Chongqing 400044, China. \\ ${ }^{2}$ Institute of Engineering Thermophysics, School of Energy and Power Engineering, Chongqing University, Chongqing 400044, China.
}

\section{HIGHLIGHTS}

$>$ Cyanobacteria may provide a potential solution for biogas upgrading.

- Significant light attenuation limited carbon capture by Spirulina platensis.

$>$ Increasing light intensity to $210 \mu \mathrm{mol} \mathrm{m}^{-2} \mathrm{~s}^{-1}$ improved S. platensis growth.

$>$ Optimal $\mathrm{NaHCO}_{3}$ concentration of $0.1 \mathrm{M}$ was

identified for bicarbonate utilization.

$>$ A biogas rate of $800 \mathrm{~m}^{3} \mathrm{~h}^{-1}$ can generate

cyanobacteria biomass of $344 \mathrm{~kg} \mathrm{~h}^{-1}$.

\section{GRAPHICAL ABSTRACT}

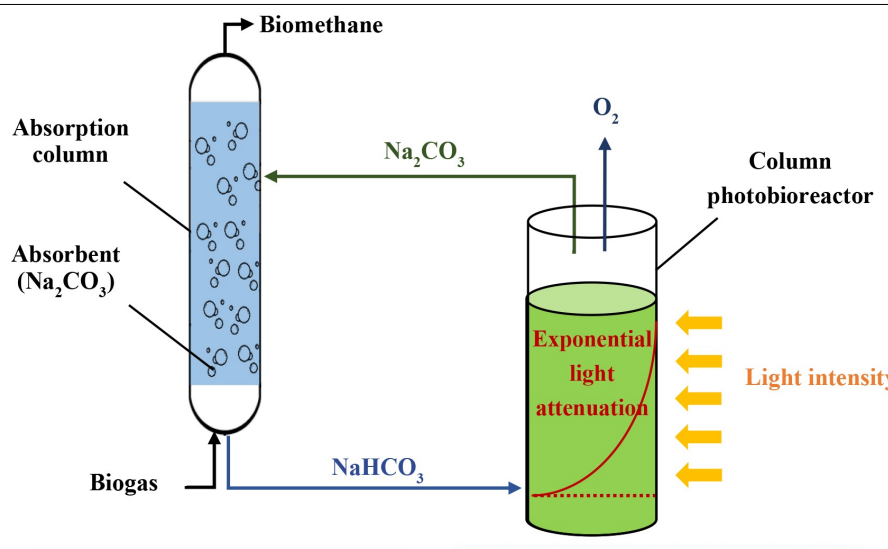

Chemical absorption:
$\mathrm{CO}_{2}+\mathrm{CO}_{3}^{2-}+\mathrm{H}_{2} \mathrm{O} \rightarrow 2 \mathrm{HCO}_{3}^{-}$
$\mathrm{CO}_{2}+\mathrm{H}_{2} \mathrm{O} \rightarrow \mathrm{HCO}_{3}^{-}+\mathrm{H}^{+}$

- Microalgae photosynthesis:

$\mathrm{HCO}_{3}^{-} \rightarrow \mathrm{CO}_{2}+\mathrm{OH}^{-}$

$6 \mathrm{CO}_{2}+6 \mathrm{H}_{2} \mathrm{O} \rightarrow \mathrm{C}_{6} \mathrm{H}_{12} \mathrm{O}_{6}+6 \mathrm{O}_{2}$

- Carbonate regeneration:

$\mathrm{HCO}_{3}^{-}+\mathrm{OH}^{-} \rightarrow \mathrm{CO}_{3}^{2-}+\mathrm{H}_{2} \mathrm{O}$

\section{ARTICLE INFO}

\section{Article history:}

Received 30 May 2020

Received in revised form 14 July 2020

Accepted 23 July 2020

Available online 1 September 2020

\section{Keywords:}

Biogas upgrading

Spirulina platensis

Light attenuation

Bicarbonate

Fermentation

\begin{abstract}
The two-step photosynthetic biogas upgrading process, which combines $\mathrm{CO}_{2}$ capture by carbonate solution and carbonate regeneration by using aquatic microbial oxygenic photoautotrophs (i.e., cyanobacteria, algae, and diatoms), may provide a potential alternative to the commercial routes used for gaseous biofuel upgrading. Such a process not only provides a green and low energy intensive biogas upgrading pathway but also converts $\mathrm{CO}_{2}$ in biogas into high value biomass. To improve the upgrading performance, the effects of light intensity and $\mathrm{NaHCO}_{3}$ concentration on the growth and the $\mathrm{HCO}_{3}{ }^{-}$transformation characteristics of halophilic and alkaliphilic Spirulina platensis were investigated in this study. Experimental results showed that the light attenuation of $S$. platensis culture was significant. Increasing light intensity up to $210 \mu \mathrm{mol} \mathrm{m}^{-2} \mathrm{~s}^{-1}$ effectively improved the $S$. platensis growth and photosynthetic pigment accumulation. S. platensis could grow in the range of 0.05 to 0.6 $\mathrm{M} \mathrm{NaHCO}_{3}$, and a maximum biomass concentration of $1.46 \mathrm{~g} \mathrm{~L}^{-1}$ was achieved under an optimal growth condition of $0.1 \mathrm{M}$ $\mathrm{NaHCO}_{3}$, which was $65.9 \%$ higher than at $0.05 \mathrm{M} \mathrm{NaHCO}_{3}$. Moreover, the bicarbonate utilization efficiency reached $42.0 \%$. Finally, in a case study, a biogas stream at a flow rate of $800 \mathrm{~m}^{3} \mathrm{~h}^{-1}$ could generate biomass up to $344 \mathrm{~kg} \mathrm{~h}^{-1}$, corresponding an energy value of $5591 \mathrm{MJ} \mathrm{h}^{-1}$.
\end{abstract}

(c) 2020 BRTeam. All rights reserved.

* Corresponding authors at: Tel.: +862365106832

E-mail address: aoxia@cqu.edu.cn

Please cite this article as: Ye W., Xia A., Chen C., Liao Q., Huang Y., Zhu X., Zhu X. Sustainable carbon capture via halophilic and alkaliphilic cyanobacteria: the role of light and bicarbonate. Biofuel Research Journal 27 (2020) 1195-1204. DOI: 10.18331/BRJ2020.7.3.3 


\section{Contents}

1. Introduction.

2. Materials and Methods

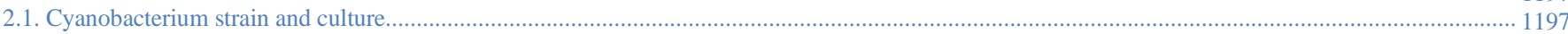

2.2. Light attenuation characteristics of cyanobacteria

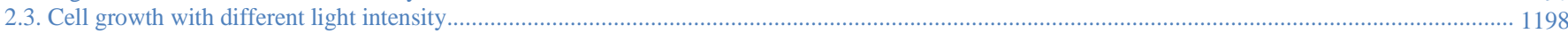

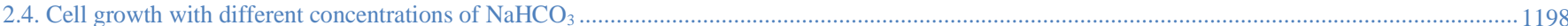

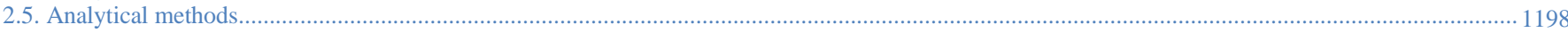

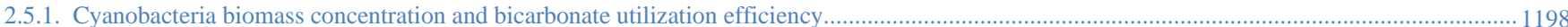

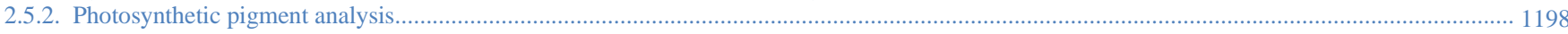

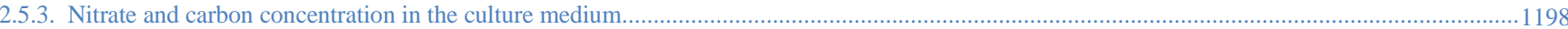

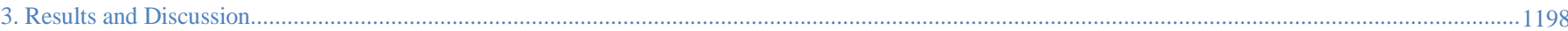

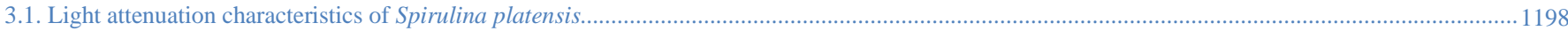

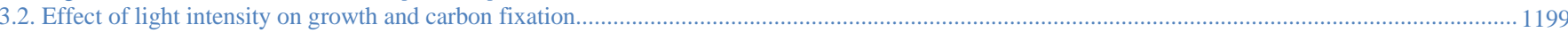

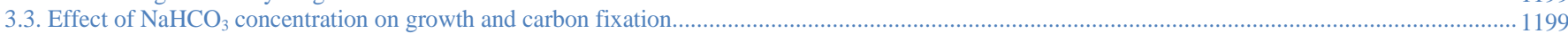

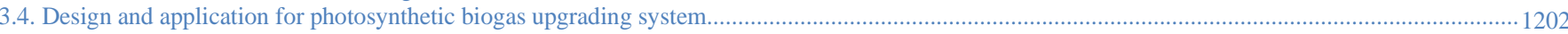

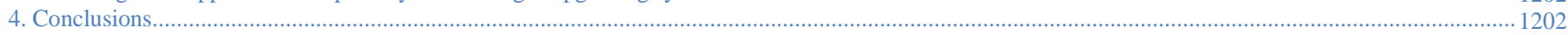

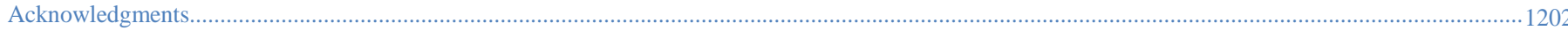

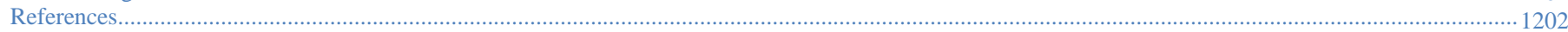

\begin{tabular}{|c|c|}
\hline \multicolumn{2}{|c|}{ Abbreviations } \\
\hline AMOPs & Aquatic microbial oxygenic photoautotrophs \\
\hline APC & Allophycocyanin \\
\hline$C$ & Carbon content of cyanobacteria biomass (\%) \\
\hline $\mathrm{CaCl}_{2}$ & Calcium chloride \\
\hline$C_{b}$ & Cyanobacteria biomass concentration \\
\hline $\mathrm{CH}_{4}$ & Methane \\
\hline Chl-a & Chlorophyll-a \\
\hline $\mathrm{Co}\left(\mathrm{NO}_{3}\right)_{2}$ & Cobalt(II) nitrate \\
\hline $\mathrm{CO}_{2}$ & Carbon dioxide \\
\hline $\mathrm{CO}_{3}^{2-}$ & Carbonate \\
\hline $\mathrm{CuSO}_{4}$ & Copper(II) sulphate \\
\hline$D C W$ & Biomass concentration $\left(\mathrm{g} \mathrm{L}^{-1}\right)$ \\
\hline $\mathrm{FeSO}_{4}$ & Iron(II) sulphate \\
\hline $\mathrm{H}_{2} \mathrm{O}$ & Water \\
\hline $\mathrm{H}_{3} \mathrm{BO}_{3}$ & Boric acid \\
\hline $\mathrm{HCO}_{3}^{-}$ & Bicarbonate \\
\hline I & The output light intensity \\
\hline$I_{0}$ & The incident light intensity \\
\hline$k_{0}$ & $\begin{array}{l}\text { The total extinction coefficient, including the } \\
\text { extinction coefficient } k_{w} \text { caused by the liquid medium } \\
\text { and the extinction coefficient } k_{b} \text { caused by the } \\
\text { cyanobacteria biomass }\end{array}$ \\
\hline $\mathrm{K}_{2} \mathrm{SO}_{4}$ & Potassium sulphate \\
\hline$l$ & $\begin{array}{l}\text { The distance the light penetrates through } \\
\text { cyanobacteria suspension }\end{array}$ \\
\hline$M_{E}$ & Dry biomass $(\mathrm{g})$ \\
\hline $\mathrm{MgSO}_{4}$ & Magnesium sulphate \\
\hline $\mathrm{MnCl}_{2}$ & Manganese(II) chloride \\
\hline $\mathrm{Na}_{2} \mathrm{CO}_{3}$ & Sodium carbonate \\
\hline $\mathrm{Na}_{2} \mathrm{MoO}_{4}$ & Sodium molybdate \\
\hline $\mathrm{NaCl}$ & Sodium chloride \\
\hline $\mathrm{NaHCO}_{3}$ & Sodium bicarbonate \\
\hline $\mathrm{NaNO}_{3}$ & Sodium nitrate \\
\hline $\mathrm{NO}_{3}^{-}$ & Nitrate \\
\hline PC & Phycocyanin \\
\hline TIC & Input total inorganic carbon $\left(\mathrm{g} \mathrm{L}^{-1}\right)$ \\
\hline$V_{e}$ & Solvent volume (L) \\
\hline$Y_{P C}$ & The content of phycocyanin (\%) \\
\hline $\mathrm{ZnSO}_{4}$ & Zinc sulphate \\
\hline
\end{tabular}

\section{Introduction}

Biogas production from crop straw, animal manure and other wastes through anaerobic fermentation has significant energy and environmental benefits (Horvath et al., 2016; Xia et al., 2016; Scarlat et al., 2018 Kamusoko et al., 2019). Biogas is mainly composed of $40 \%-75 \% \mathrm{CH}_{4}$, $15 \%-50 \% \mathrm{CO}_{2}$, and other components such as $\mathrm{O}_{2}(0-1 \%), \mathrm{N}_{2}(0-2 \%)$, water vapour $(1 \%-10 \%), \mathrm{H}_{2} \mathrm{~S}(0-10,000 \mathrm{ppm})$, ammonia $(0-100 \mathrm{ppm})$, siloxanes $(0-0.02 \%)$, and halogenated hydrocarbons $(\mathrm{VOC}<0.6 \%)$ (Munoz et al., 2015; Ryckebosch et al., 2011). High levels of $\mathrm{CO}_{2}$ reduce the calorific value of biogas, increase the emission of carbon monoxide and hydrocarbons during combustion, and contribute to the greenhouse effect. Biogas can be upgraded by decarbonization to obtain high quality biomethane, which is an important alternative to conventional natural gas.

Conventional physical/chemical technologies for biogas upgrading such as water, organic solvent and chemical scrubbing, pressure swing adsorption, membrane separation, and cryogenic separation are currently available commercially, but these technologies have high requirements for operation conditions, complex equipment structure, and high energy consumption, which limit their economic and environmental sustainability for biogas upgrading (Khan et al., 2017). Energy requirements of these technologies range between 0.12 to $0.77 \mathrm{kWh} \mathrm{m}^{-3}$ of upgraded biogas (consuming 3\%-6\% of the energy of the produced biogas), while the capital investment costs are $0.10-0.40 € \mathrm{~m}^{-3}$ of biogas (Patterson et al., 2011; Xia et al., 2015; Gotz et al., 2016)

Alternatively, photosynthetic biogas upgrading can utilize aquatic microbial oxygenic photoautotrophs (AMOPs) to fix $\mathrm{CO}_{2}$ while obtaining microbial biomass that can be used for further production of high valueadded products (Dismukes et al., 2008; Mata et al., 2010; Kumar et al., 2016; Velazquez-Lucio et al., 2018). One of the major bottlenecks of direct biogas upgrading by using AMOPs is the release of photosynthetic oxygen, which leads to contamination of biomethane and a potential explosive hazard (Posadas et al., 2015; Franco-Morgado et al., 2018). In contrast, two-step photosynthetic biogas upgrading separates the two processes of AMOPs cultivation and biogas upgrading and is considered as an effective solution to reduce the oxygen content in upgraded gaseous biofuel (ToledoCervantes et al., 2017).

As shown in Figure 1, in the first step, the carbon dioxide content of biogas can be efficiently captured by carbonate solution forming bicarbonate. In the second step, bicarbonate is used as a carbon source for AMOPs cultivation. AMOPs can absorb and utilize bicarbonate through carbon concentration mechanism and produce organic carbon through photosynthesis. During their growth and metabolism, the $\mathrm{pH}$ of the medium increases gradually, leading to carbonate regeneration and realizing the carbonate/bicarbonate cycle (Xia et al., 2015).

To improve the efficiency of the photosynthetic biogas upgrading, improving AMOPs growth and the carbonate regeneration rate are very important. A number of studies have reported AMOPs cultivation using concentrated $\mathrm{CO}_{2}$ at various concentrations. However, very few studies 

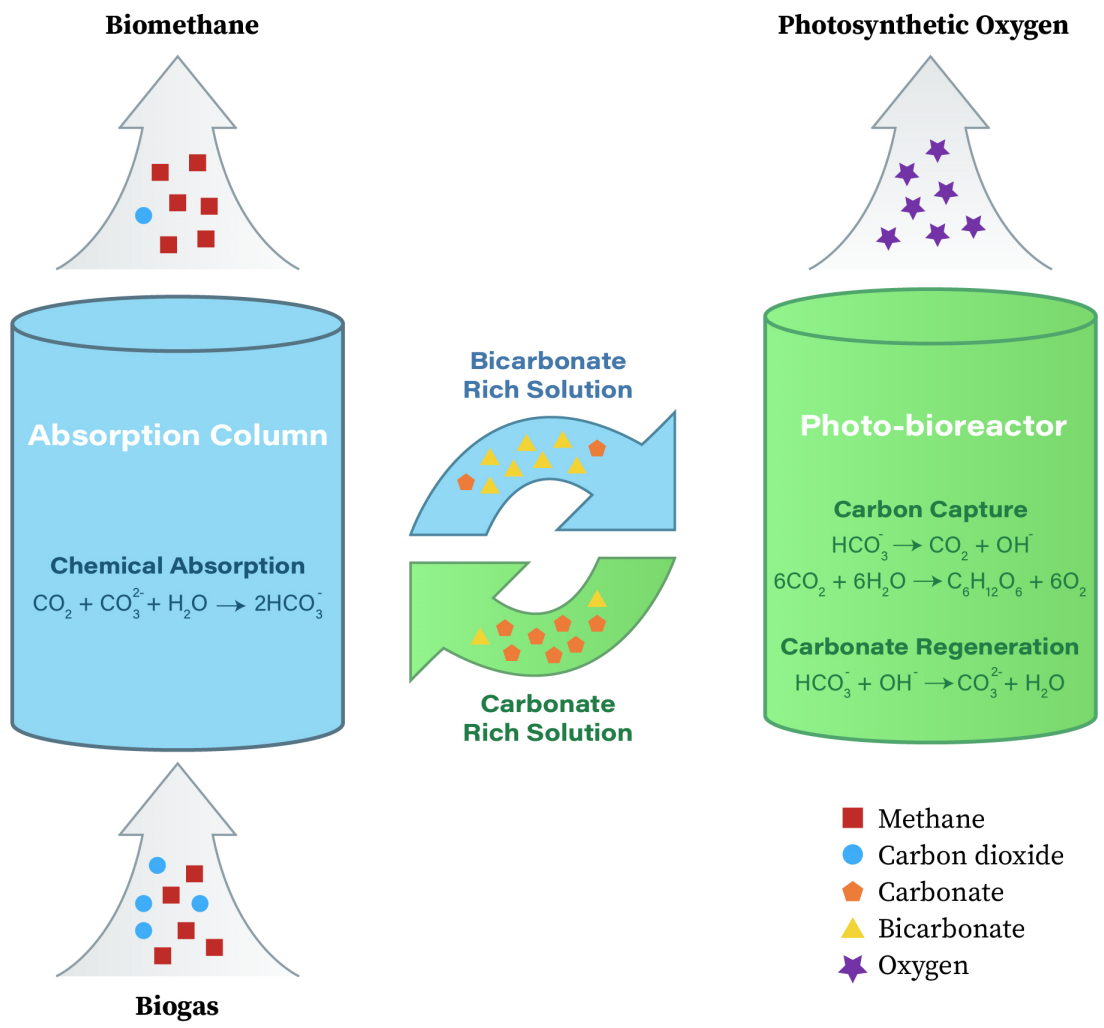

Fig. 1. Two-step photosynthetic biogas upgrading via carbonate/bicarbonate cycle

have focused on the impacts of environmental parameters on carbon utilization and AMOPs growth during the two-step photosynthetic biogas upgrading process. Unlike AMOPs grown in a $\mathrm{CO}_{2}$ environment, only bicarbonate is employed as carbon source in these systems. Moreover, gas spargers may not be required in such AMOPs systems, thereby leading to different growth and carbon fixation behaviours for AMOPs.

The cyanobacteria (also known as blue green microalgae) Spirulina platensis is tolerant to high alkalinity and high salinity conditions and is considered as a candidate for photosynthetic biogas upgrading (Xia et al., 2015). The effect of light transmission on microalgae growth is a primary point of concern (Carvalho et al., 2011; Cheng et al., 2013). Sun et al. (2018b) found that light attenuation reduced the light utilization efficiency of Chlorella vulgaris. It should be noted that filamentous $S$. platensis has completely different light absorption and scattering characteristics from spherical $C$. vulgaris. Nevertheless, there is also a lack of relevant research.

The innovation of this study is that it comprehensively investigates the effect of environmental parameters on the growth and bicarbonate transformation characteristics of halophilic and alkaliphilic S. platensis for photosynthetic biogas upgrading. The objectives are to investigate the light transmission characteristics in S. platensis culture, to assess the effects of light intensity and $\mathrm{NaHCO}_{3}$ concentration on bicarbonate utilization and cyanobacteria growth, and to discuss the design and application of the photosynthetic biogas upgrading system.

\section{Materials and Methods}

\subsection{Cyanobacterium strain and culture}

The haloalkaliphilic cyanobacterium strain S. platensis FACHB-439 was purchased from the Freshwater Algae Culture Collection of Hydrobiology, Chinese Academy of Science (China). The cyanobacterium was grown on the Schlösser (1982) medium: $13.61 \mathrm{~g} \mathrm{~L}^{-1} \mathrm{NaHCO}_{3}, 4.03 \mathrm{~g} \mathrm{~L}^{-1} \mathrm{Na}_{2} \mathrm{CO}_{3}, 2.50 \mathrm{~g} \mathrm{~L}^{-1}$ $\mathrm{NaNO}_{3}, 0.50 \mathrm{~g} \mathrm{~L}^{-1} \mathrm{~K}_{2} \mathrm{HPO}_{4}, 1.00 \mathrm{~g} \mathrm{~L}^{-1} \mathrm{~K}_{2} \mathrm{SO}_{4}, 1.00 \mathrm{~g} \mathrm{~L}^{-1} \mathrm{NaCl}, 0.20 \mathrm{~g}$
$\mathrm{L}^{-1} \mathrm{MgSO}_{4} \cdot 7 \mathrm{H}_{2} \mathrm{O}, 0.04 \mathrm{~g} \mathrm{~L}^{-1} \mathrm{CaCl}_{2} \cdot 2 \mathrm{H}_{2} \mathrm{O}, 0.01 \mathrm{~g} \mathrm{~L}^{-1} \mathrm{FeSO}_{4} \cdot 7 \mathrm{H}_{2} \mathrm{O}, 2.86$ $\mathrm{mg} \mathrm{L}^{-1} \mathrm{H}_{3} \mathrm{BO}_{3}, 1.86 \mathrm{mg} \mathrm{L}^{-1} \mathrm{MnCl}_{2} \cdot 4 \mathrm{H}_{2} \mathrm{O}, 0.22 \mathrm{mg} \mathrm{L}^{-1} \mathrm{ZnSO}_{4} \cdot 7 \mathrm{H}_{2} \mathrm{O}, 0.39$ $\mathrm{mg} \mathrm{L} \mathrm{Na}_{2} \mathrm{MoO}_{4} \cdot 2 \mathrm{H}_{2} \mathrm{O}, 0.08 \mathrm{mg} \mathrm{L}{ }^{-1} \mathrm{CuSO}_{4} \cdot 5 \mathrm{H}_{2} \mathrm{O}$, and $0.05 \mathrm{mg} \mathrm{L}$ $\mathrm{Co}\left(\mathrm{NO}_{3}\right)_{2} \cdot 6 \mathrm{H}_{2} \mathrm{O}$. Culturing was conducted with a polymethyl methacrylate column photobioreactor $(120 \mathrm{~mm}$ outer diameter, $3 \mathrm{~mm}$ thick, and $200 \mathrm{~mm}$ high), containing $1500 \mathrm{~mL}$ of the medium with the operational conditions of shaking at $300 \mathrm{rpm}$ and temperature at $33^{\circ} \mathrm{C}$. All cultivation experiments were conducted with an identical inoculated initial $\mathrm{OD}_{443}$ value of 0.27 .

\subsection{Light attenuation characteristics of cyanobacteria}

The Lambert Beer's law was used to describe the light attenuation characteristics in the suspension of cyanobacteria cells (Zhang et al., 2015), as shown in Equation 1.

$I=I_{0} \cdot \exp \left(-k_{0} l\right)$

where $I$ represents the output light intensity, $I_{0}$ denotes the incident light intensity, and $l$ refers to the distance the light penetrates through cyanobacteria suspension. $k_{0}$ is the total extinction coefficient, including the extinction coefficient $k_{w}$ caused by the liquid medium and the extinction coefficient $k_{b}$ caused by the cyanobacteria biomass, as shown in Equation 2.

$k_{0}=k_{b} C_{b}+k_{w}$

where $C_{b}$ represents the cyanobacteria biomass concentration.

To determine the coefficients $k_{b}$ and $k_{w}$, the incident light intensity in the internal surface of the photobioreactor was measured by a light quantum meter, and was set to $120 \mu \mathrm{mol} \mathrm{m} \mathrm{m}^{-2} \mathrm{~s}^{-1}$ by adjusting the luminous power of a surface light source. The output light intensity of 42 different combinations were simultaneously tested: 7 different levels of $C_{b}$, from 0 
to $0.706 \mathrm{~g} \mathrm{~L}^{-1}$, and 6 levels of $l$, from 1 to $6 \mathrm{~cm}$. After obtaining the corresponding total extinction coefficient $k_{0}$ at different biomass concentrations, linear fitting of $k_{0}$ and $C_{b}$ was performed according to Equation 2. It was assumed that the incident light intensity was 80 and $210 \mu \mathrm{mol} \mathrm{m} \mathrm{m}^{-2} \mathrm{~s}^{-1}$, and the cyanobacteria biomass concentration was $0.05,0.3$ and $0.8 \mathrm{~g} \mathrm{~L}^{-1}$. Subsequently, the corresponding cyanobacteria light attenuation curve under each working condition was obtained from Equation 1.

\subsection{Cell growth with different light intensity}

Modified medium was used for the cultures to adjust the concentrations of $\mathrm{NaHCO}_{3}, \mathrm{NaNO}_{3}$, and $\mathrm{Na}_{2} \mathrm{CO}_{3}$ to $25.2,1.5$, and $0 \mathrm{~g} \mathrm{~L}^{-1}$, respectively. Three light intensities $\left(80,150,210 \mu \mathrm{mol} \mathrm{m}^{-2} \mathrm{~s}^{-1}\right)$ were set to measure the growth and carbon fixation characteristics of cyanobacteria in the culture cycle (Kebede and Ahlgren, 1996; Chi et al., 2013; Bahr et al., 2014; Chi et al., 2014). All other cultivation parameters were as described in Section 2.1.

\subsection{Cell growth with different concentrations of $\mathrm{NaHCO}_{3}$}

The $\mathrm{NaHCO}_{3}, \mathrm{NaNO}_{3}$, and $\mathrm{Na}_{2} \mathrm{CO}_{3}$ concentration in the medium were also regulated; $\mathrm{NaNO}_{3}$ and $\mathrm{Na}_{2} \mathrm{CO}_{3}$ were set to 1.5 and $0 \mathrm{~g} \mathrm{~L}^{-1}$, respectively, and $\mathrm{NaHCO}_{3}$ was set to $0.05,0.1,0.3,0.6$, or $1.0 \mathrm{M}$ to measure the growth and carbon fixation characteristics of cyanobacteria in the culture cycle. The batch was cultivated under a light intensity of $210 \mu \mathrm{mol} \mathrm{m}^{-2} \mathrm{~s}^{-1}$. All other cultivation parameters were as described in Section 2.1.

\subsection{Analytical methods}

\subsubsection{Cyanobacteria biomass concentration and bicarbonate utilization} efficiency

During cultivation, a $10 \mathrm{~mL}$ cell suspension sample was filtered daily with a filter membrane with an aperture of $5 \mu \mathrm{m}$. The cell pellet was then washed with $10 \mathrm{~mL}$ of deionized water 4 times. After washing, the sample was dried in an oven at $85^{\circ} \mathrm{C}$ overnight to obtain the biomass concentration gravimetrically.

Bicarbonate utilization efficiency $\eta(\%)$ was defined as the percentage of fixed carbon in total input carbon (Kim et al., 2017), as shown in Equation 3.

$\eta=[C(\%) \cdot D C W] / T I C$

where $C(\%)$ is the carbon content of cyanobacteria biomass, DCW $\left(\mathrm{g} \mathrm{L}^{-1}\right)$ stands for the biomass concentration, and TIC $\left(\mathrm{g} \mathrm{L}^{-1}\right)$ denotes the input total inorganic carbon concentration in the culture system.

\subsubsection{Photosynthetic pigment analysis}

Photosynthetic pigments in $S$. platensis include phycobiliprotein, chlorophyll-a (Chl-a), and carotenoid. The Chl-a (mg L$\left.{ }^{-1}\right)$ and carotenoid (mg $\mathrm{L}^{-1}$ ) were assayed using the method of Harmut (1987). They were calculated according to Equations 4 and 5.

Chl-a $=16.72 A_{665.2}-9.16 A_{652.4}$

Carotenoid $=\left(1000 A_{470}-1.63 \cdot C h l-a\right) / 221$

The phycobiliprotein of $S$. platensis includes phycocyanin (PC) and allophycocyanin (APC). The PC $\left(\mathrm{g} \mathrm{L}^{-1}\right)$ and APC $\left(\mathrm{g} \mathrm{L}^{-1}\right)$ were measured according to the method of Manirafasha et al. (2018), as shown in Equations 6 and 7.
$P C=\left(A_{615}-0.474 A_{652}\right) / 5.34$

$A P C=\left(A_{652}-0.208 A_{615}\right) / 5.09$

The content of phycocyanin $Y_{P C}(\%)$ was calculated according to Equation 8 (Silveira et al., 2008).

$Y_{P C}=\left(\frac{P C \times V_{e}}{M_{E}}\right) \times 100 \%$

where $V_{e}(\mathrm{~L})$ represents the solvent volume and $M_{E}(\mathrm{~g})$ is the dry biomass.

\subsubsection{Nitrate and carbon concentration in the culture medium}

For the measurement of residual nitrate and carbon concentration in culture medium, $1 \mathrm{~mL}$ of cell suspension was sampled daily from the photobioreactor, and then it was filtered to obtain the supernatant. Then, nitrate concentration was measured according to the method of Collos et al. (1999). The total inorganic carbon (TIC) concentration in the sample was measured by a total organic carbon (TOC) analyser (Multi N/C 3000 analyser, Analytikjena, Germany). Thereafter, the concentrations of $\mathrm{CO}_{2}$, $\mathrm{HCO}_{3}{ }^{-}$and $\mathrm{CO}_{3}{ }^{2-}$ in the supernatant were calculated according to the Roy's method (Roy et al., 1993).

\section{Results and Discussion}

\subsection{Light attenuation characteristics of Spirulina platensis}

The total extinction coefficient $k_{0}$ was obtained by measuring the output light intensity under different cyanobacteria biomass concentrations and distances from light incident surface, as shown in Table 1 . The relationship between $k_{0}$ and $C_{b}$ could be obtained, according to Equation 9. Consequently, the light attenuation formula in cell suspension of $S$. platensis is shown in Equation 10.

$k_{0}=3.2774 C_{b}+0.1813\left(R^{2}=0.9883\right)$

(Eq. 9)

$I=I_{0} \times \exp \left[-\left(3.2774 C_{b}+0.1813\right) \times l\right]$

As shown in Figure 2, when light entered the cyanobacteria suspension, the light attenuated exponentially along the direction of light transmission, resulting in uneven distribution of light intensity in the photobioreactor, which was not conducive to cyanobacteria growth. When the incident light intensity was $210 \mu \mathrm{mol} \mathrm{m}^{-2} \mathrm{~s}^{-1}$ and the distance from light incident surface was $1 \mathrm{~cm}$, as biomass concentration increased from 0.05 to $0.8 \mathrm{~g} \mathrm{~L}^{-1}$, the light intensity significantly decreased by $29.2 \%$ to $93.9 \%$. The increasing distance and decreasing incident light intensity also led to the reduced output light intensity.

The causes of light attenuation mainly include light absorption by photosynthetic pigments in microalgae cells, light scattering by microalgae cells, and the mutual shielding between microalgae cells (Sun et al., 2016). Therefore, the type and content of pigment, concentration of microalgae cells, light intensity, and distance from light incident surface can all affect the light transmission in the photobioreactor. Interestingly, the extinction coefficient $k_{b}$ of $S$. platensis was 2.8 times higher than that of Chlorella vulgaris (Sun et al., 2018b). In other words, the light attenuation degree of S. platensis was much higher than that of Chlorella vulgaris. This is because the $S$. platensis cells are large and filamentous $(5-10 \mu \mathrm{m}$ in width

Table 1.

Fitted values of $k_{0}$ under different cyanobacteria biomass concentrations.

\begin{tabular}{llllllll}
\hline $\boldsymbol{C}_{\boldsymbol{b}}\left(\mathrm{g} \mathrm{L}^{-1}\right)$ & $\mathbf{0}$ & $\mathbf{0 . 0 6 7}$ & $\mathbf{0 . 2 2 5}$ & $\mathbf{0 . 4 1 4}$ & $\mathbf{0 . 4 8 4}$ & $\mathbf{0 . 5 9 3}$ & $\mathbf{0 . 7 0 6}$ \\
\hline $\boldsymbol{I}_{\boldsymbol{\theta}}\left(\boldsymbol{\mu \mathrm { mol } \mathrm { m } \mathbf { ~ } ^ { - 2 } \mathbf { s } ^ { - 1 } )}\right.$ & 120 & 120 & 120 & 120 & 120 & 120 & 120 \\
$\boldsymbol{k}_{\boldsymbol{\theta}}\left(\mathbf{c m}^{-1}\right)$ & 0.1613 & 0.3946 & 0.9478 & 1.5529 & 1.6742 & 2.3059 & 2.3896 \\
\hline $\mathbf{R}^{2}$ & 0.9404 & 0.9728 & 0.9987 & 0.9956 & 0.9976 & 0.9867 & 0.9990 \\
\hline
\end{tabular}




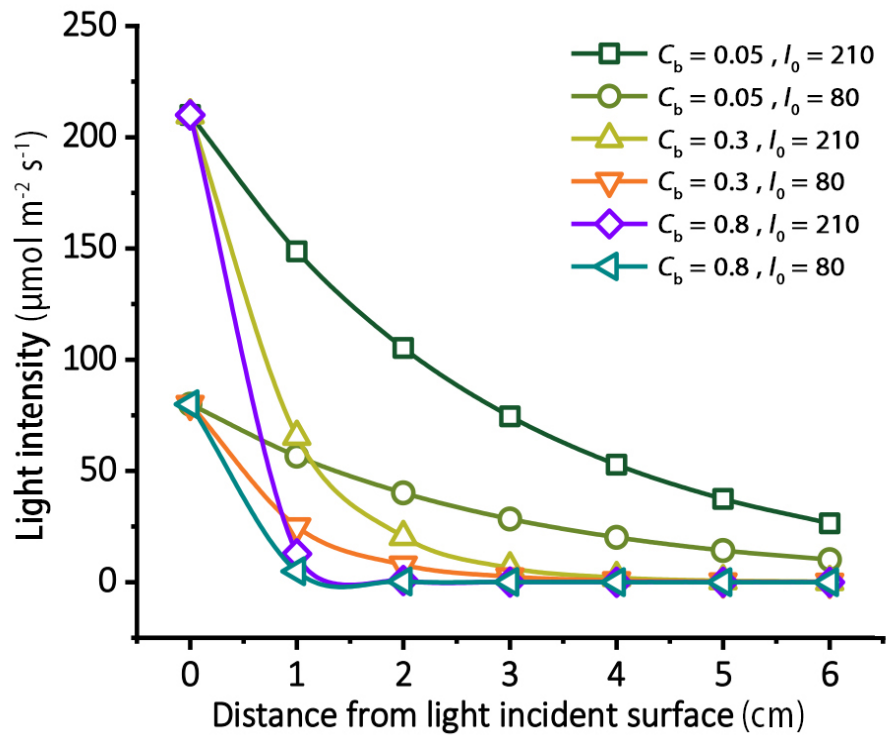

Fig. 2. Light intensity distribution with different biomass concentrations and distances from light incident surface under incident light intensities of 80 and $210 \mu \mathrm{mol} \mathrm{m}^{-2} \mathrm{~s}^{-1}$.

and $50-500 \mu \mathrm{m}$ in length), which leads to a serious light shielding and light attenuation phenomenon. The results indicated that high light intensity may be favourable for the photosynthetic carbon fixation of S. platensis.

\subsection{Effect of light intensity on growth and carbon fixation}

The biomass concentration and residual $\mathrm{NO}_{3}{ }^{-}$concentration in cyanobacteria suspension under different light intensities changed with cultivation time. As light intensity increased from 80 to $210 \mu \mathrm{mol} \mathrm{m}^{-2} \mathrm{~s}^{-1}$, the maximum biomass concentration significantly increased from 0.67 to $0.98 \mathrm{~g} \mathrm{~L}^{-1}$ (Fig. 3a). Moreover, the maximum specific growth rate of $1.64 \mathrm{~d}^{-1}$ was observed at a light intensity of $210 \mu \mathrm{mol} \mathrm{m} \mathrm{m}^{-2} \mathrm{~s}^{-1}$, which was 1.42 times higher than the minimum light intensity condition. Liu et al. (2014) found that compared to low light intensity conditions, the maximum biomass concentration of Chlorella sp. and Scenedesmus obliquus sp. reached $1.4 \mathrm{~g} \mathrm{~L}^{-1}$ with a light intensity of 6800 lux. The $\mathrm{NO}_{3}$ concentration in cyanobacteria suspension decreased with increasing light intensity. On the $10^{\text {th }}$ day, the residual concentration of $\mathrm{NO}_{3}{ }^{-}$at the light intensity of $210 \mu \mathrm{mol} \mathrm{m} \mathrm{m}^{-2} \mathrm{~s}^{-1}$ decreased by $43.7 \%$ from the initial stage, which was the largest decrease recorded (Fig. 3b). Bicarbonate utilization efficiency under the light intensity of $210 \mu \mathrm{mol} \mathrm{m} \mathrm{m}^{-2} \mathrm{~s}^{-1}$ was 1.5 times higher than the minimum light intensity condition. These results suggested that high light intensity could facilitate the growth and carbon fixation of cyanobacteria. However, the biomass concentration or nutrient absorption efficiency at the light intensity of $210 \mu \mathrm{mol} \mathrm{m}^{-2} \mathrm{~s}^{-1}$ was not significantly different from that of the light intensity of $150 \mu \mathrm{mol} \mathrm{m} \mathrm{m}^{-2} \mathrm{~s}^{-1}$. Therefore, methods to increase cyanobacteria biomass could include not only increasing light intensity but also suppressing light attenuation, through methods such as periodic harvesting of cyanobacteria or development of a novel photobioreactor that can decrease the distance from light incident surface or alter light/dark cycle frequency (Ye et al., 2019).

S. platensis biomass can be used to extract high value-added products, such as pigments, including Chl-a, carotenoid, and phycocyanin (Lima et al., 2018). As shown in Figure 4a, the contents of Chl-a and carotenoid in cyanobacteria cells increased with increasing light intensity. PC is a blue-coloured accessory photosynthetic pigment and mainly captures light energy by absorbing light over a range of wavelengths (such as orange-yellow light) that chlorophyll uses insufficiently (Eriksen, 2008a). It has multiple applications in antioxidants, cosmetics, medicines, and health products production (Kissoudi et al., 2018). The PC concentration at the light intensity of $210 \mu \mathrm{mol} \mathrm{m}^{-2} \mathrm{~s}^{-1}$ was $0.89 \mathrm{~g} \mathrm{~L}^{-1}$, which was $14.9 \%$ of the dry biomass. (Fig. $4 \mathrm{~b}$ ). There was no significant difference in the contents of Chl-a, carotenoid and phycobiliprotein under different light intensities, possibly because light intensity was not the primarily
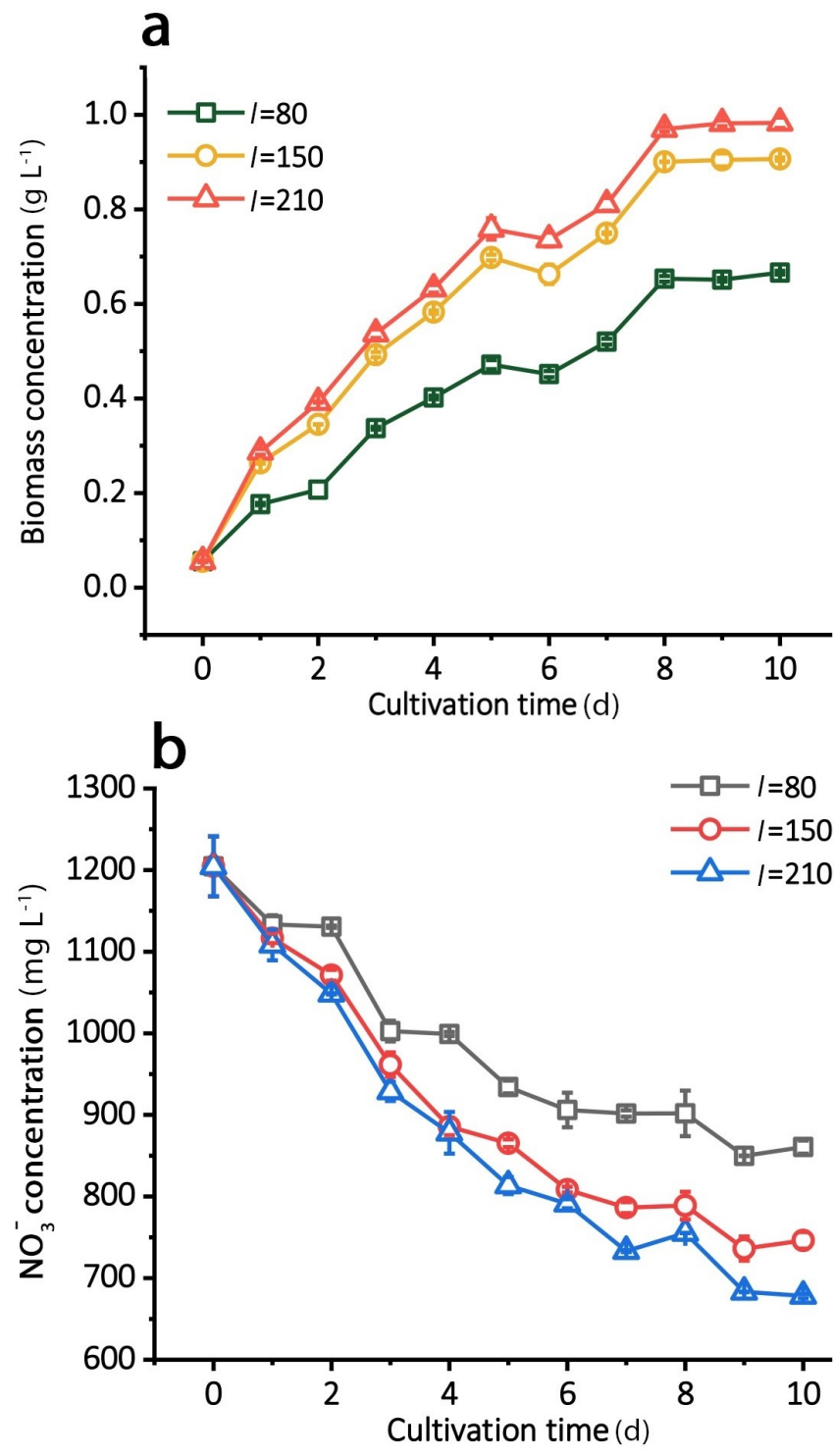

Fig. 3. Effect of light intensity on (a) biomass concentration and (b) $\mathrm{NO}_{3}{ }^{-}$concentration in cyanobacteria suspension during cultivation.

limiting factor of pigment accumulation at this time. del Rio-Chanona et al (2015) found that the Spirulina biomass concentration in outdoor raceway ponds hardly exceeded $0.8 \mathrm{~g} \mathrm{~L}^{-1}$, and the PC content was only approximately $7 \%$ of the dry biomass. Göksan and Kilıç (2009) and de Jesus et al. (2018) also found that lower light intensity was not conducive to biomass and PC accumulation of Spirulina. Therefore, the optimal light intensity of $210 \mu \mathrm{mol} \mathrm{m}^{-2} \mathrm{~s}^{-1}$ was selected for further trials.

\subsection{Effect of $\mathrm{NaHCO}_{3}$ concentration on growth and carbon fixation}

The biomass concentration of $S$. platensis changed dramatically at different $\mathrm{NaHCO}_{3}$ concentrations, as shown in Figure 5a. The results showed that the maximum biomass concentration of $1.46 \mathrm{~g} \mathrm{~L}^{-1}$ was observed on the $8^{\text {th }}$ day under an optimal growth condition of $0.1 \mathrm{M}$ $\mathrm{NaHCO}_{3}$, which was $65.9 \%$ higher than $0.05 \mathrm{M} \mathrm{NaHCO}_{3}$. Compared with the cell growth of $0.1 \mathrm{M} \mathrm{NaHCO}_{3}$, partial inhibition occurred in $0.05,0.3$, and $0.6 \mathrm{M}$, and severe inhibition occurred in $1.0 \mathrm{M}$. On the $9^{\text {th }}$ day, the residual concentration of $\mathrm{NO}_{3}^{-}$at $0.1 \mathrm{M} \mathrm{NaHCO}_{3}$ decreased by $48.7 \%$ from the initial stage, which was the largest decrease recorded (Fig. 5b). The bicarbonate utilization efficiency decreased with increasing $\mathrm{NaHCO}_{3}$ 
a

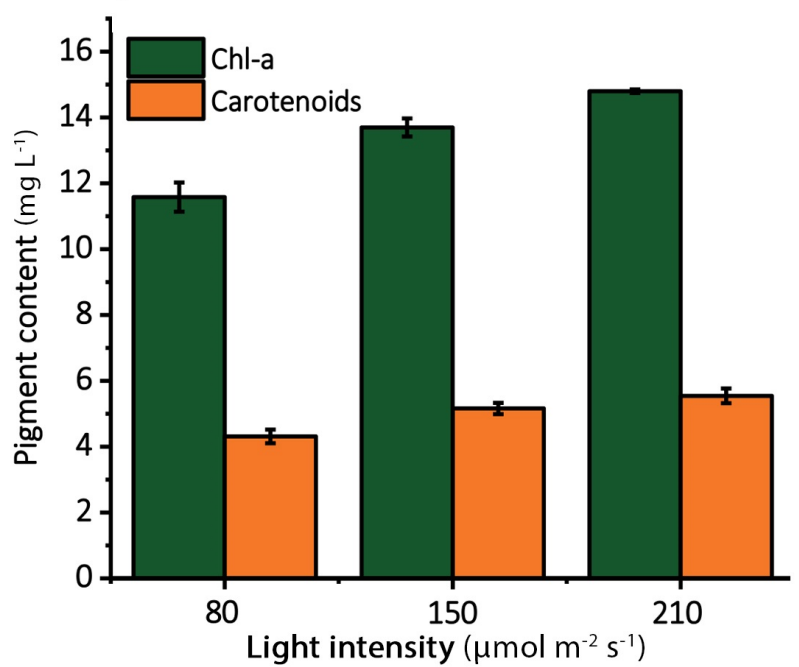

b

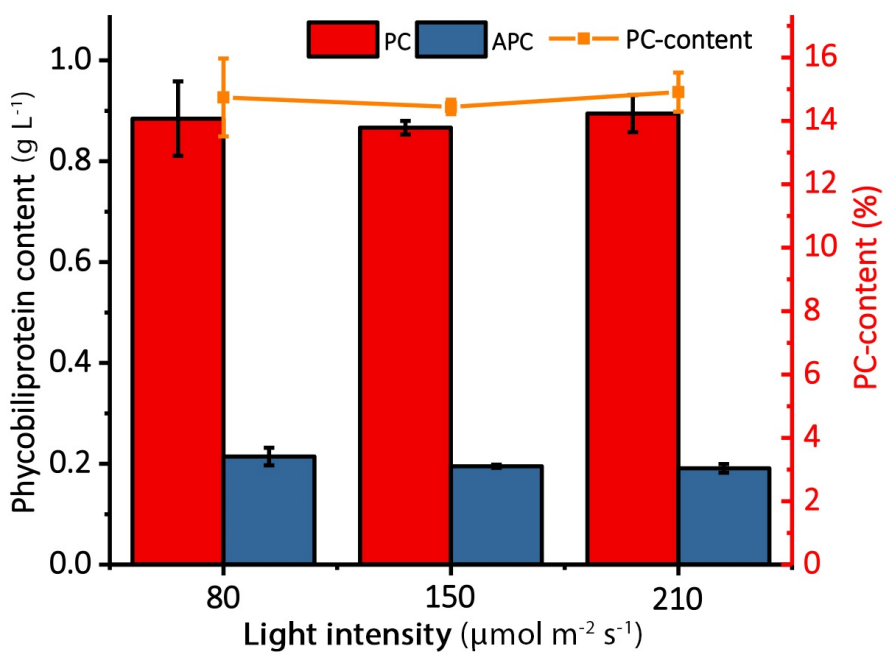

Fig. 4. Variations in (a) pigment and (b) phycobiliprotein in cyanobacteria cells under different light intensities.

concentration from $0.1 \mathrm{M}$ to $0.6 \mathrm{M}$, and maximum bicarbonate utilization efficiency of $42.0 \%$ was achieved at $0.1 \mathrm{M} \mathrm{NaHCO}_{3}$, which was 7.8 times higher than at $0.6 \mathrm{M} \mathrm{NaHCO}_{3}$. This was because the carbon content of $0.05 \mathrm{M}$ $\mathrm{NaHCO}_{3}$ was too low that limited cyanobacteria growth. Moreover, salinity can seriously affect osmotic pressure, nutrient absorption rate, and suspension characteristics of microalgae cells (Pisal et al., 2005; Razzak et al., 2013). High salinity may lead to reduced activity of various enzymes or transporters in cells and consumption of more energy for maintaining the osmotic pressure balance (Ho et al., 2014). The effect of $\mathrm{NaHCO}_{3}$ concentration on salinity in cyanobacteria suspension during cultivation was also investigated. The results showed that the salinity of the medium increased with the increase of $\mathrm{NaHCO}_{3}$ concentration. During the cultivation, the maximum salinity of cyanobacteria solution ranged from $5.03 \%$ to $36.70 \%$ when $\mathrm{NaHCO}_{3}$ concentration ranged from $0.05 \mathrm{M}$ to $1.0 \mathrm{M}$, respectively. Therefore, high $\mathrm{NaHCO}_{3}$ concentration led to a serious salt stress on cyanobacteria cells. Additionally, the $\mathrm{pH}$ of $0.1 \mathrm{M}$ $\mathrm{NaHCO}_{3}$ was too high (close to 12) at the late stage of cyanobacteria cultivation, which inhibited the growth of cyanobacteria cells, resulting in an obvious reduction in biomass concentration compared with the maximum value.

The changes in TIC (including $\mathrm{HCO}_{3}{ }^{-}, \mathrm{CO}_{3}{ }^{2-}$, and $\mathrm{CO}_{2}$ ) concentration in cyanobacteria suspension with cultivation time could also indirectly explain the growth and carbon fixation characteristics of cyanobacteria. Compared to the a

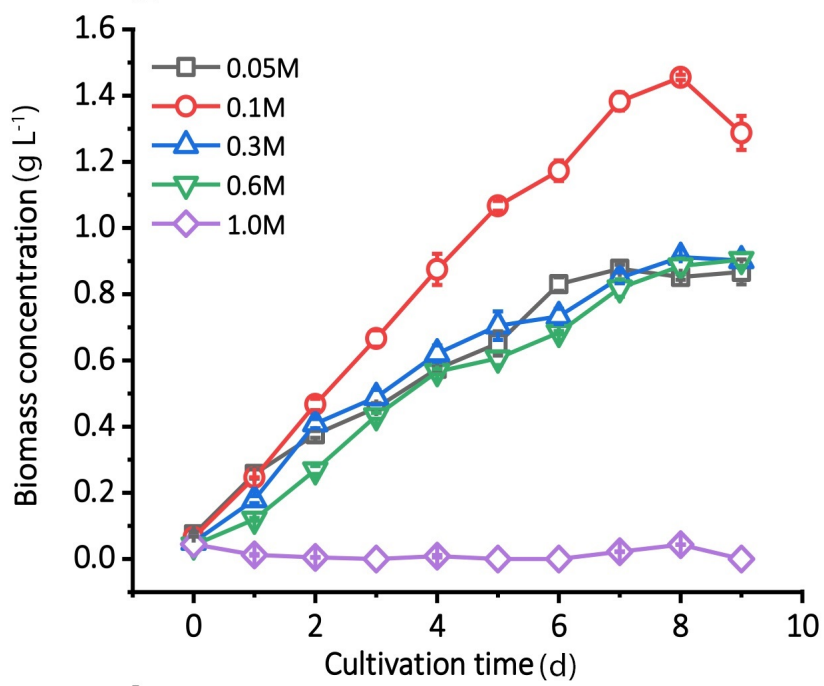

b

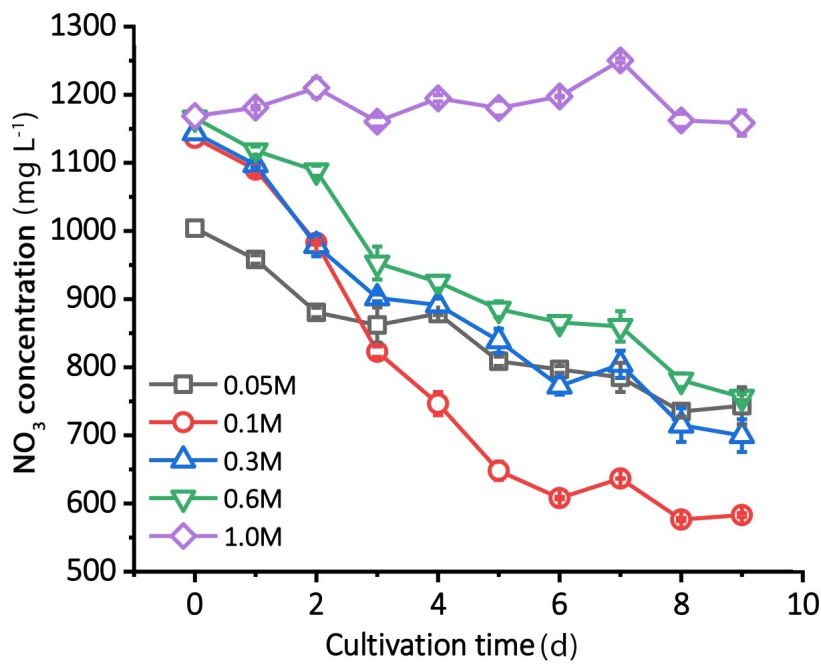

Fig. 5. Effect of $\mathrm{NaHCO}_{3}$ concentration on (a) biomass concentration and (b) $\mathrm{NO}$ concentration in cyanobacteria suspension during cultivation.

initial stage, as $\mathrm{NaHCO}_{3}$ concentration increased from 0.1 to $1.0 \mathrm{M}$, the TIC concentration on the $9^{\text {th }}$ day significantly decreased by $62.0 \%$ to $19.7 \%$. Additionally, the reduced TIC concentration at $0.1 \mathrm{M} \mathrm{NaHCO}_{3}$ was 1.3 times higher than that of $0.05 \mathrm{M} \mathrm{NaHCO}_{3}$ (Fig. 6). It could be observed that carbonate was effectively regenerated during the growth and metabolism of cyanobacteria, to reduce the energy consumption of absorbent regeneration and operating cost (Chi et al., 2011). The $\mathrm{HCO}_{3}$ content on the $2^{\text {nd }}$ day was $29.5 \%$ and $57.1 \%$ of the remaining TIC content at $0.05 \mathrm{M}$ and $0.1 \mathrm{M} \mathrm{NaHCO}_{3}$, respectively, while it was reduced to $2.2 \%$ and $1.1 \%$ on $5^{\text {th }}$ day. The results showed that the carbonate regeneration rate was high under $0.05 \mathrm{M}$ and $0.1 \mathrm{M} \mathrm{NaHCO}_{3}$. Nevertheless, $0.05 \mathrm{M}$ $\mathrm{NaHCO}_{3}$ was seriously insufficient for cyanobacteria growth.

As shown in Figure 7a, the maximum Chl-a concentration of $20.48 \mathrm{mg}$ $\mathrm{L}^{-1}$ was achieved at $0.1 \mathrm{M} \mathrm{NaHCO}_{3}$, which was 4.4 times higher than that at $0.05 \mathrm{M} \mathrm{NaHCO}_{3}$. The carotenoid concentration at $0.1 \mathrm{M} \mathrm{NaHCO}_{3}$ was 1.6 times higher than at $0.05 \mathrm{M} \mathrm{NaHCO}_{3}$. Bicarbonate significantly changed the biomass and various biochemical components such as pigments in the microalgae cells. These findings were in line with those of the previous studies (Chi et al., 2013; White et al., 2013; Pancha et al., 2015; Nayak et al., 2018). However, the salt stress caused by high $\mathrm{NaHCO}_{3}$ concentration $(0.3$ to $1.0 \mathrm{M})$ on cyanobacteria cells was serious, and inhibited the growth and pigment accumulation of cyanobacteria. 
a
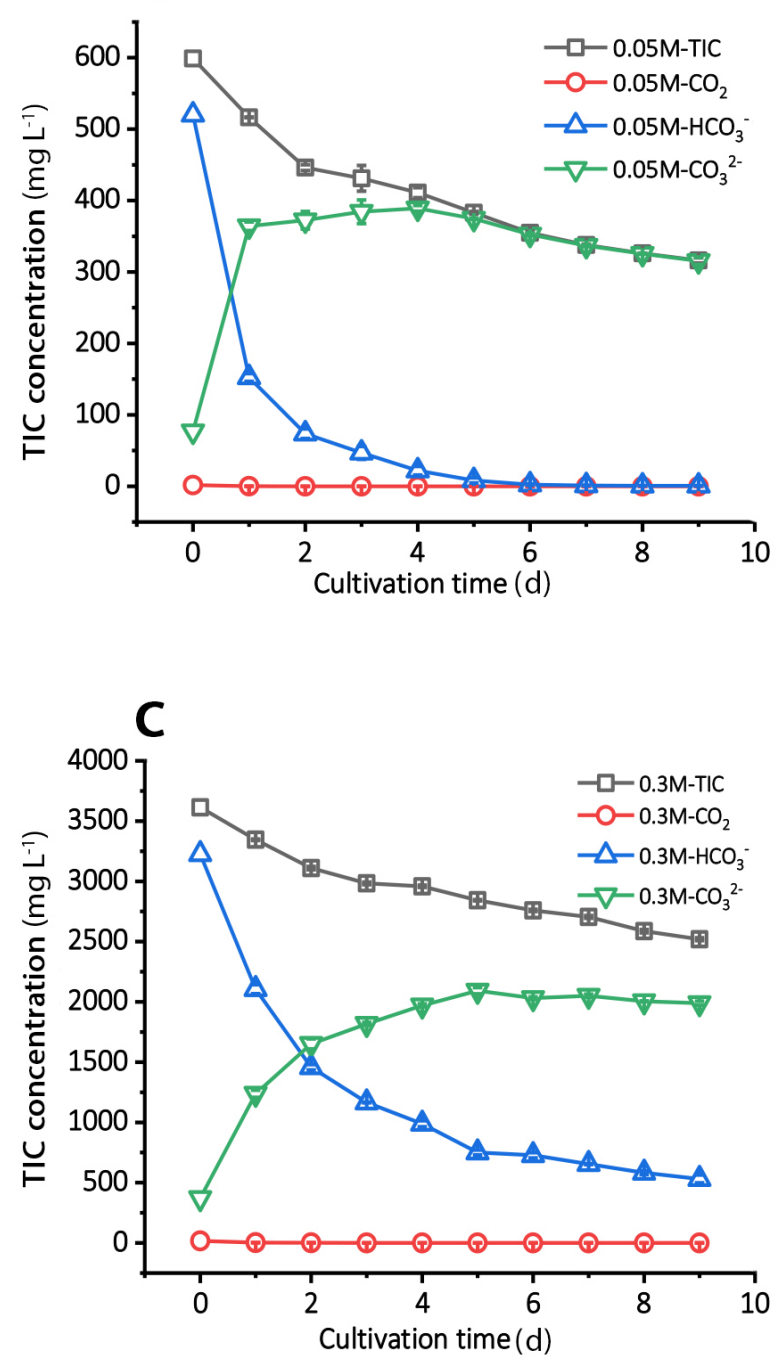
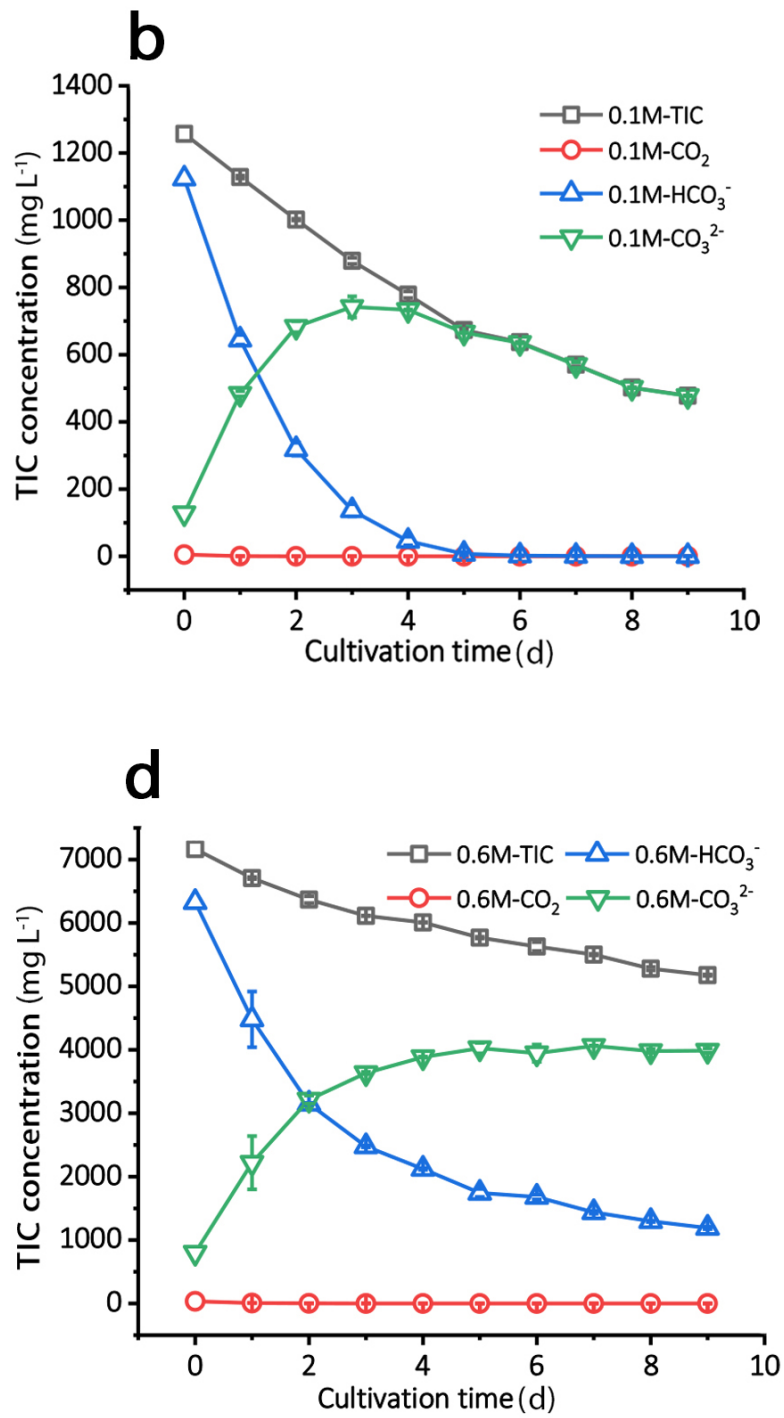

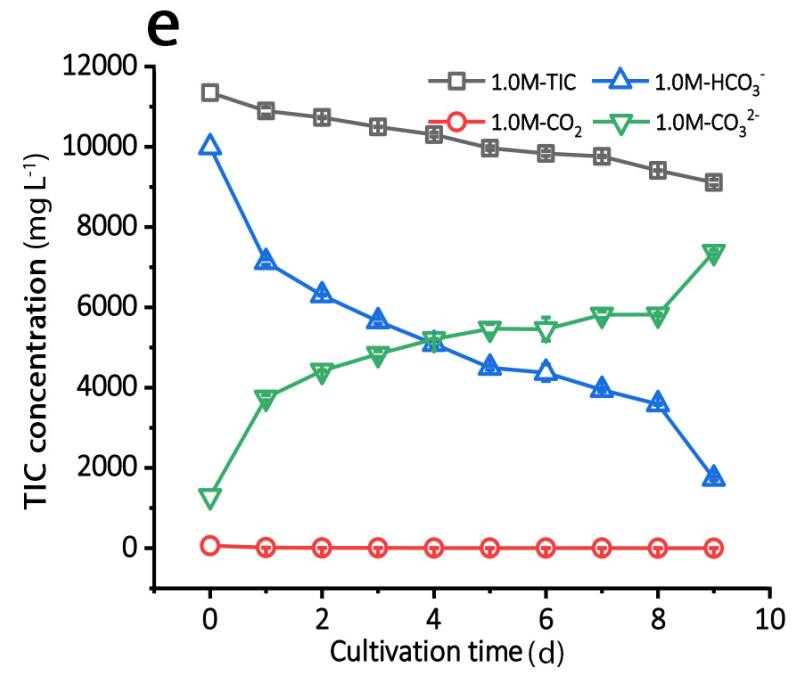

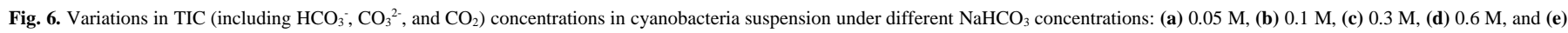
$1.0 \mathrm{M}$. 
a

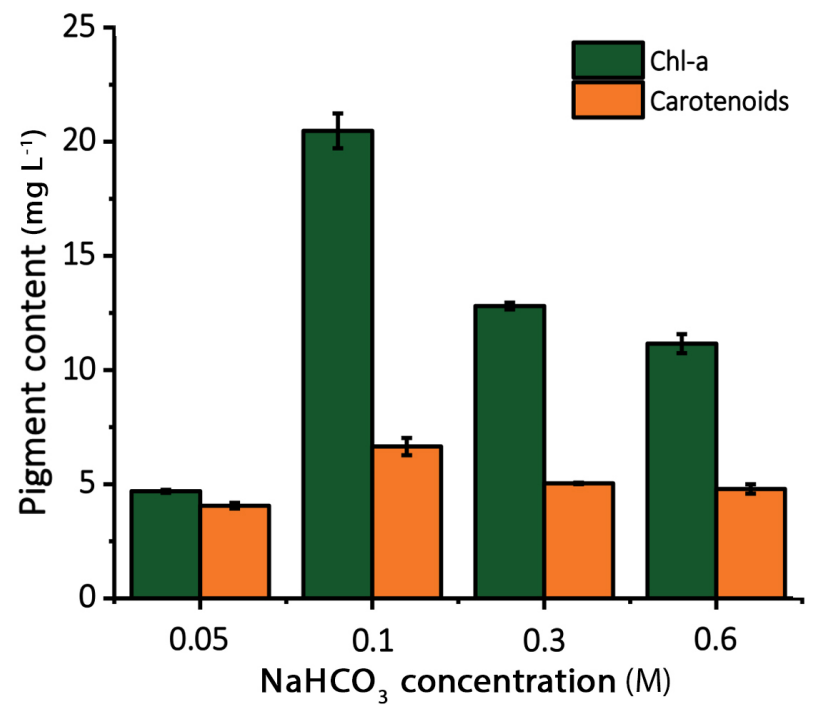

b

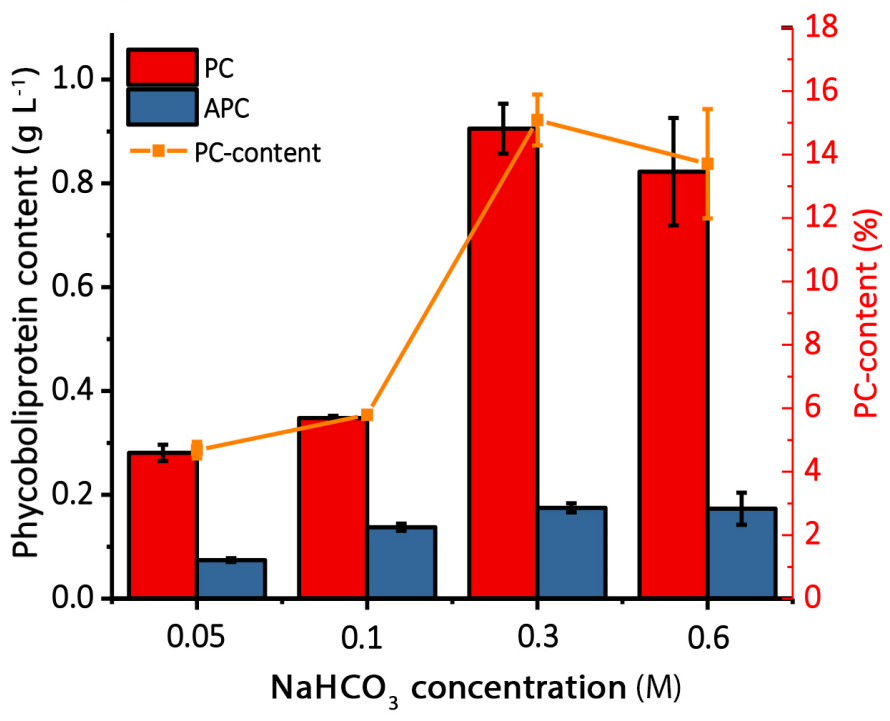

Fig. 7. Variations in (a) pigment and (b) phycobiliprotein in cyanobacteria cells under different $\mathrm{NaHCO}_{3}$ concentrations.

Moreover, the maximum PC concentration of $0.91 \mathrm{~g} \mathrm{~L}^{-1}$ was achieved at 0.3 $\mathrm{M} \mathrm{NaHCO}_{3}$, which was 3.2 times higher than at $0.05 \mathrm{M} \mathrm{NaHCO}_{3}$. The PC content of $0.3 \mathrm{M} \mathrm{NaHCO}_{3}$ accounted for $13.7 \%$ of dry biomass, which was 2.6 times higher than that of $0.1 \mathrm{M} \mathrm{NaHCO}_{3}$ (Fig. 7b). Studies found that unfavourable environments lead to the decomposition of phycobiliprotein (especially PC) to provide nutrients needed for cyanobacteria growth, thus maintaining the normal metabolic function of cyanobacteria (Eriksen, 2008b). Compared with the maximum biomass concentration at $0.1 \mathrm{M} \mathrm{NaHCO}_{3}$, the value on the $9^{\text {th }}$ day decreased by $11.5 \%$ due to the high $\mathrm{pH}$ of the later growth stage. Therefore, the phycobiliprotein content of $0.1 \mathrm{M} \mathrm{NaHCO}_{3}$ was much lower. Compared to freshwater microalgae species, these results demonstrated that $S$. platensis had a favourable tolerance to high saline-alkaline environments while possessing promising capabilities to regenerate carbonate.

\subsection{Design and application for photosynthetic biogas upgrading system}

According to the experimental results of cyanobacteria cultivation, a case study was carried out to set up a photosynthetic biogas upgrading system. The biogas production of this project to treat cow manure and straw was set at $800 \mathrm{~m}^{3} \mathrm{~h}^{-1}$ and $S$. platensis was selected as the working cyanobacteria species. Since after capturing the $\mathrm{CO}_{2}$ of biogas, the $0.05 \mathrm{M}$ $\mathrm{Na}_{2} \mathrm{CO}_{3}$ absorbent was conducive to cyanobacteria growth, the average biomass productivity of $S$. platensis was recorded at $0.2 \mathrm{~g} \mathrm{~L}^{-1} \mathrm{~d}^{-1}$ under the condition of $0.1 \mathrm{M} \mathrm{NaHCO}_{3}$.

Moreover, producing $1 \mathrm{t}$ of AMOPs biomass fixes approximately 1.83 tons of $\mathrm{CO}_{2}$ (Chisti, 2007). Accordingly, the amount of total biomass produced was $344 \mathrm{~kg} \mathrm{~h}^{-1}$ when the cyanobacteria fixed all the $\mathrm{CO}_{2}$ contained in the produced biogas. Therefore, the cultivation volume of cyanobacteria in the column photobioreactor was $41280 \mathrm{~m}^{3}$. The low calorific value of biogas with $60 \%-65 \% \mathrm{CH}_{4}$ is $20-25 \mathrm{MJ} \mathrm{m}^{-3}$ (Angelidaki et al., 2018). According to Xia et al. (2014), the calorific value of S. platensis was calculated to be $19.15 \mathrm{~kJ} \mathrm{~g}^{-1}$ VS. Given the fact that the volatile solids content accounts for $85 \%$ of the microalgae total solids (Sun et al., 2018a), the total calorific value of microalgae could reach $5591 \mathrm{MJ} \mathrm{h}^{-1}$, which is equivalent to $280 \mathrm{~m}^{3} \mathrm{~h}^{-1}$ of biogas. This made up one third of the system's biogas production, indicating that the photosynthetic biogas upgrading had a promising development potential.

\section{Conclusions}

The halophilic and alkaliphilic S. platensis was demonstrated to be a potential candidate for sustainable carbon capture and biogas upgrading. Severe light attenuation was observed in filamentous $S$. platensis culture; the extinction coefficient in S. platensis was 2.8 times higher than that of spherical C. vulgaris. The maximum biomass concentration was $0.98 \mathrm{~g} \mathrm{~L}^{-1}$ at the light intensity of $210 \mu \mathrm{mol} \mathrm{m}^{-2} \mathrm{~s}^{-1}$, which was $47.6 \%$ higher than that of $80 \mu \mathrm{mol} \mathrm{m} \mathrm{m}^{-2} \mathrm{~s}^{-1}$. $\mathrm{NaHCO}_{3}$ concentration significantly affected cyanobacteria biomass and pigment production. The optimal biomass concentration of $1.46 \mathrm{~g} \mathrm{~L}^{-1}$ was achieved at an $\mathrm{NaHCO}_{3}$ concentration of $0.1 \mathrm{M}$, which was $65.9 \%$ higher than that of $0.05 \mathrm{M} \mathrm{NaHCO}_{3}$. Meanwhile, the bicarbonate utilization efficiency reached $42.0 \%$. Cyanobacteria biomass of up to $344 \mathrm{~kg} \mathrm{~h}^{-1}$ could be generated with the biogas flow rate of $800 \mathrm{~m}^{3} \mathrm{~h}^{-1}$, corresponding to an energy value of $5591 \mathrm{MJ} \mathrm{h}^{-1}$ (i.e., that of one third of the biogas produced).

\section{Acknowledgements}

This work was supported by the National Key Research and Development Program of China (No. 2016YFB0601002), the National Natural Science Foundation of China (No. 51961165104), the State Key Program of National Natural Science of China (No. 51836001), the Venture \& Innovation Support Program for Chongqing Overseas Returnees (No. cx2019040), and the Young Elite Scientists Sponsorship Program by CAST (2018QNRC001).

\section{References}

[1] Angelidaki, I., Treu, L., Tsapekos, P., Luo, G., Campanaro, S. Wenzel, H., Kougias, P.G., 2018. Biogas upgrading and utilization: current status and perspectives. Biotechnol. Adv. 36(2), 452-466.

[2] Bahr, M., Díaz, I., Dominguez, A., Gonzalez Sanchez, A., Muñoz, R. 2014. Microalgal-biotechnology as a platform for an integral biogas upgrading and nutrient removal from anaerobic effluents. Environ. Sci. Technol. 48(1), 573-581.

[3] Carvalho, A.P., Silva, S.O., Baptista, J.M., Malcata, F.X., 2011. Light requirements in microalgal photobioreactors: an overview of biophotonic aspects. Appl. Microbiol. Biotechnol. 89(5), 1275-1288.

[4] Cheng, Y., Luo, X., Zheng, Z., 2013. Effects of various LED light qualities and light intensity supply strategies on purification of slurry from anaerobic digestion process by Chlorella vulgaris. Int. Biodeterior. Biodegrad. 79, 81-87.

[5] Chi, Z., Elloy, F., Xie, Y., Hu, Y., Chen, S., 2014. Selection of microalgae and cyanobacteria strains for bicarbonate-based integrated 
carbon capture and algae production system. Appl. Biochem. Biotechnol. 172(1), 447-457.

[6] Chi, Z., Xie, Y., Elloy, F., Zheng, Y., Hu, Y., Chen, S., 2013. Bicarbonate-based integrated carbon capture and algae production system with alkalihalophilic cyanobacterium. Bioresour. Technol. 133, 513-521.

[7] Chi, Z., O'Fallon, J.V., Chen, S., 2011. Bicarbonate produced from carbon capture for algae culture. Trends Biotechnol. 29(11), 537-541.

[8] Chisti, Y., 2007. Biodiesel from microalgae. Biotechnol. Adv. 25(3), 294306

[9] Collos, Y., Mornet, F., Sciandra, A., Waser, N., Larson, A., Harrison, P.J., 1999. An optical method for the rapid measurement of micromolar concentrations of nitrate in marine phytoplankton cultures. J. Appl. Phycol. 11(2), 179-184.

[10] de Jesus, C.S., da Silva Uebel, L., Costa, S.S., Miranda, A.L., de Morais, E.G., de Morais, M.G., Costa, J.A.V., Nunes, I.L., de Souza Ferreira, E., Druzian, J.I., 2018. Outdoor pilot-scale cultivation of Spirulina sp LEB18 in different geographic locations for evaluating its growth and chemical composition. Bioresour. Technol. 256, 86-94.

[11] del Rio-Chanona, E.A., Zhang, D., Xie, Y., Manirafasha, E., Jing, K., 2015. Dynamic simulation and optimization for Arthrospira platensis growth and C-phycocyanin production. Ind. Eng. Chem. Res. 54(43), 10606-10614

[12] Dismukes, G.C., Carrieri, D., Bennette, N., Ananyev, G.M., Posewitz, M.C., 2008. Aquatic phototrophs: efficient alternatives to land-based crops for biofuels. Curr. Opin. Biotechnol. 19(3), 235-240.

[13] Eriksen, N.T., 2008a. Production of phycocyanin-a pigment with applications in biology, biotechnology, foods and medicine. Appl. Microbiol. Biotechnol. 80(1), 1-14.

[14] Eriksen, N.T., 2008b. The technology of microalgal culturing. Biotechnol. Lett. 30(9), 1525-1536.

[15] Franco-Morgado, M., Toledo-Cervantes, A., Gonzalez-Sanchez, A., Lebrero, R., Munoz, R., 2018. Integral ( $\mathrm{VOC}_{\mathrm{s}}, \mathrm{CO}_{2}$, mercaptans and $\mathrm{H}_{2} \mathrm{~S}$ ) photosynthetic biogas upgrading using innovative biogas and digestate supply strategies. Chem. Eng. J. 354, 363-369.

[16] Schlösser, U.G., 1982. Sammlung von algenkulturen. Ber. Deutsch. Bot. Ges. 95(1), 181-276

[17] Göksan, T., Kılıç, C., 2009. Growth and biochemical composition of Spirulina platensis Geitler in summer period under the conditions of Çanakkale, Turkey. Asian J. Chem. 21(6), 4947-4950.

[18] Gotz, M., Lefebvre, J., Mors, F., Koch, A.M., Graf, F., Bajohr, S., Reimert, R., Kolb, T., 2016. Renewable power-to-gas: a technological and economic review. Renewable Energy. 85, 1371-1390.

[19] Harmut, A., 1987. Chlorophylls and carotenoids: pigments of photosynthetic biomembranes. Method Enzymol. 148, 350-382.

[20] Ho, S.H., Ye, X., Hasunuma, T., Chang, J.S., Kondo, A., 2014. Perspectives on engineering strategies for improving biofuel production from microalgae-A critical review. Biotechnol. Adv. 32(8), 1448-1459.

[21] Kamusoko, R., Jingura, R.M., Parawira, W., Sanyika, W.T., 2019. Comparison of pretreatment methods that enhance biomethane production from crop residues-a systematic review. Biofuel Res. J. 6(4), 1080-1089.

[22] Kebede, E., Ahlgren, G., 1996. Optimum growth conditions and light utilization efficiency of Spirulina platensis (=equals Arthrospira fusiformis) (Cyanophyta) from Lake Chitu, Ethiopia. Hydrobiologia. 332(2), 99-109.

[23] Khan, I.U., Othman, M.H.D., Hashim, H., Matsuura, T., Ismail, A.F., Rezaei-DashtArzhandi, M., Azelee, I.W., 2017. Biogas as a renewable energy fuel-a review of biogas upgrading, utilisation and storage. Energy Convers. Manage. 150, 277-294

[24] Kim, G.Y., Heo, J., Kim, H.S., Han, J.I., 2017. Bicarbonate-based cultivation of Dunaliella salina for enhancing carbon utilization efficiency. Bioresour. Technol. 237, 72-77.

[25] Kissoudi, M., Sarakatsianos, I., Samanidou, V., 2018. Isolation and purification of food-grade C-phycocyanin from Arthrospira platensis and its determination in confectionery by HPLC with diode array detection. J. Sep. Sci. 41(4), 975-981.

[26] Kumar, G., Zhen, G., Sivagurunathan, P., Bakonyi, P., Nemestóthy, N., Bélafi-Bakó, K., Kobayashi, T., Xu, K.Q., 2016. Biogenic $\mathrm{H}_{2}$ production from mixed microalgae biomass: impact of $\mathrm{pH}$ control and methanogenic inhibitor (BESA) addition. Biofuel Res. J. 3(3), 470-474.
[27] Lima, G.M., Teixeira, P.C., Teixeira, C.M., Filocomo, D., Lage, C.L. 2018. Influence of spectral light quality on the pigment concentrations and biomass productivity of Arthrospira platensis. Algal Res. 31, 157-166.

[28] Liu, G., Qiao, L., Zhang, H., Zhao, D., Su, X., 2014. The effects of illumination factors on the growth and $\mathrm{HCO}_{3}$-fixation of microalgae in an experiment culture system. Energy. 78, 40-47.

[29] Manirafasha, E., Murwanashyaka, T., Ndikubwimana, T., Ahmed, N.R., Liu, J., Lu, Y., Zeng, X., Ling, X.P., Jing, K., 2018 Enhancement of cell growth and phycocyanin production in Arthrospira (Spirulina) platensis by metabolic stress and nitrate fedbatch. Bioresour. Technol. 255, 293-301.

[30] Mata, T.M., Martins, A.A., Caetano, N.S., 2010. Microalgae for biodiesel production and other applications: a review. Renew. Sust. Energy Rev. 14(1), 217-232.

[31] Munoz, R., Meier, L., Diaz, I., Jeison, D., 2015. A review on the stateof-the-art of physical/chemical and biological technologies for biogas upgrading. Rev. Environ. Sci. Bio/Technol. 14(4), 727-759.

[32] Nayak, M., Suh, W.I., Lee, B., Chang, Y.K., 2018. Enhanced carbon utilization efficiency and FAME production of Chlorella sp $\mathrm{HS}_{2}$ through combined supplementation of bicarbonate and carbon dioxide. Energy Convrs. Manage. 156, 45-52.

[33] Pancha, I., Chokshi, K., Ghosh, T., Paliwal, C., Maurya, R., Mishra, S., 2015. Bicarbonate supplementation enhanced biofuel production potential as well as nutritional stress mitigation in the microalgae Scenedesmus sp CCNM 1077. Bioresour. Technol. 193, 315-323.

[34] Patterson, T., Esteves, S., Dinsdale, R., Guwy, A., 2011. An evaluation of the policy and techno-economic factors affecting the potential for biogas upgrading for transport fuel use in the UK. Energy Policy. 39(3), 1806-1816.

[35] Pisal, D.S., Lele, S.S., 2005.Carotenoid production from microalga. Indian J. Biotechnol. 4(4), 476-483.

[36] Posadas, E., Serejo, M.L., Blanco, S., Perez, R., Garcia-Encina, P.A. Munoz, R., 2015. Minimization of biomethane oxygen concentration during biogas upgrading in algal-bacterial photobioreactors. Algal Res. 12, 221-229.

[37] Razzak, S.A., Hossain, M.M., Lucky, R.A., Bassi, A.S., de Lasa, H., 2013. Integrated $\mathrm{CO}_{2}$ capture, wastewater treatment and biofuel production by microalgae culturing-a review. Renew. Sust. Energy Rev. 27, 622-653.

[38] Roy, R.N., Roy, L.N., Vogel, K.M., Porter-Moore, C., Pearson, T., Good, C.E., Millero, F.J., Campbell, D.M., 1993. The dissociation constants of carbonic acid in seawater at salinities 5 to 45 and temperatures 0 to $45^{\circ} \mathrm{C}$. Mar. Chem. 44(2-4), 249-267.

[39] Ryckebosch, E., Drouillon, M., Veruaeren, H., 2011. Techniques for transformation of biogas to biomethane. Biomass Bioenergy. 35(5), 1633-1645.

[40] Horváth, I.S., Tabatabaei, M., Karimi, K., Kumar, R., 2016. Recen updates on biogas production-a review. Biofuel Res. J. 3(2), 394-402.

[41] Scarlat, N., Dallemand, J.F., Fahl, F., 2018. Biogas: development and perspectives in Europe. Renewable Energy. 129, 457-472.

[42] Silveira, S.T., de Menezes Quines, L.K., Burkert, C.A.V., Kalil, S.J., 2008. Separation of phycocyanin from Spirulina platensis using ion exchange chromatography. Bioprocess. Biosyst. Eng. 31(5), 477-482.

[43] Sun, Y., Liao, Q., Huang, Y., Xia, A., Fu, Q., Zhu, X., Zheng, Y. 2016. Integrating planar waveguides doped with light scattering nanoparticles into a flat-plate photobioreactor to improve light distribution and microalgae growth. Bioresour. Technol. 220, 215 224.

[44] Sun, C., Xia, A., Liao, Q., Fu, Q., Huang, Y., Zhu, X., Wei, P., Lin, R., Murphy, J.D., 2018a. Improving production of volatile fatty acids and hydrogen from microalgae and rice residue: effects of physicochemical characteristics and mix ratios. Appl. Energy. 230, 1082-1092.

[45] Sun, Y., Liao, Q., Huang, Y., Xia, A., Fu, Q., Zhu, X., Fu, J., Li, J., 2018b. Application of growth-phase based light-feeding strategies to simultaneously enhance Chlorella vulgaris growth and lipid accumulation. Bioresour. Technol. 256, 421

[46] Toledo-Cervantes, A., Madrid-Chirinos, C., Cantera, S., Lebrero, R., Munoz, R., 2017. Influence of the gas-liquid flow configuration in the 
absorption column on photosynthetic biogas upgrading in algal-bacterial photobioreactors. Bioresour. Technol. 225, 336-342.

[47] Velazquez-Lucio, J., Rodriguez-Jasso, R.M., Colla, L.M., SaenzGalindo, A., Cervantes-Cisneros, D.E., Aguilar, C.N., Fernandes, B.D., Ruiz, H.A., 2018. Microalgal biomass pretreatment for bioethanol production: a review. Biofuel Res. J. 5(1), 780-791.

[48] White, D.A., Pagarette, A., Rooks, P., Ali, S.T., 2013. The effect of sodium bicarbonate supplementation on growth and biochemical composition of marine microalgae cultures. J. Appl. Phycol. 25(1), 153165 .

[49] Xia, A., Cheng, J., Ding, L.K., Lin, R.C., Song, W.L., Zhou, J.H., Cen, K.F., 2014. Enhancement of energy production efficiency from mixed biomass of Chlorella pyrenoidosa and cassava starch through combined hydrogen fermentation and methanogenesis. Appl. Energy. 120, 23-30.

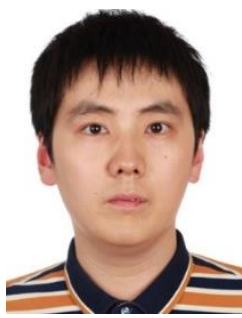

Dr. Ao Xia is a professor in the School of Energy and Power Engineering at the Chongqing University. He completed his $\mathrm{PhD}$ in 2013 in Energy Engineering at the Zhejiang University. He worked as a post-doctoral researcher in the Environmental Research Institute at the University College Cork during 2014-2016. He serves as an Associate Editor for Frontiers in Bioengineering and Biotechnology and Frontiers in Energy Research, and also serves as an editorial board member for Current Biochemical Engineering. He was selected as one of Young Elite Scientists sponsored by the China Association for Science and Technology and Hundred Talents Program of Chongqing.

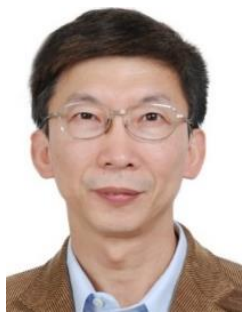

Dr. Qiang Liao is a professor and the dean of School of Energy and Power Engineering at the Chongqing University, where he heads the Institute of Engineering Thermophysics. He has more than 400 peer-reviewed journal papers and has a number of conference presentations, with a total citation of near 6000 times from peer-reviewed publications. He is on the editorial board of eight journals such as Science Bulletin, Energy, Fuel, and Applied Thermal Engineering. He has served as temporal Representative of China in International Energy Agency (IEA) Hydrogen Implementing Agreement (HIA) Task 34. He has been awarded as the Distinguished Professor Cheung Kong Scholars from the Education Ministry of China and the Distinguished Young Scholar from the National Natural Science Foundation of China.

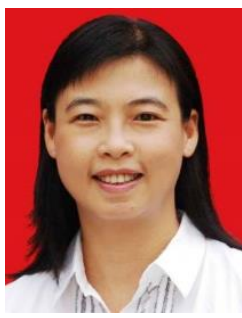

Dr. Xun Zhu is a professor in the School of Energy and Power Engineering at the Chongqing University. She has published more than 350 peer-reviewed journal papers. According to Scopus, her work has been cited over 5400 times in peer-reviewed publications. She serves as an editorial board member for Chinese Science Bulletin. She has delivered a number of keynote/invited speeches in high impact national and international conferences, including the International Heat Transfer Conference. She has received numerous prestigious awards, including the Distinguished Young Scholar and the Leading Scientist of Ten Thousand Talent Program in China.
[50] Xia, A., Herrmann, C., Murphy, J.D., 2015. How do we optimize third-generation algal biofuels?. Biofuels, Bioprod. Biorefin. 9(4), 358-367.

[51] Xia, A.. Jacob, A., Tabassum, M.R., Herrmann, C., Murphy, J.D., 2016. Production of hydrogen, ethanol and volatile fatty acids through co-fermentation of macro- and micro-algae. Bioresour. Technol. 205, $118-125$

[52] Ye, Q., Cheng, J., Lai, X., An, Y., Chu, F., Zhou, J., Cen, K., 2019. Promoting Photochemical Efficiency of Chlorella PY-ZU1 with Enhanced Velocity Field and Turbulent Kinetics in a Novel Tangential Spiral-Flow Column Photobioreactor. ACS Sust. Chem. Eng. 7(1), 384-393.

[53] Zhang, D.D., Dechatiwongse, P., Hellgardt, K., 2015. Modelling light transmission, cyanobacterial growth kinetics and fluid dynamics in a laboratory scalemultiphase photo-bioreactor for biological hydrogen production. Algal Res. 8, 99-107.

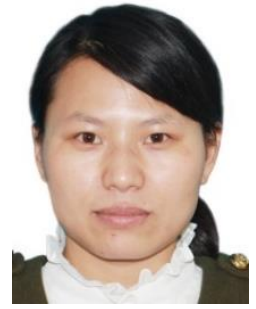

Dr. Yun Huang is an associate Professor at the School of Energy and Power Engineering at the Chongqing University, China. She was involved in research on Life Cycle analysis of $\mathrm{CO}_{2}$ fixation by microalgae from coal-fired flue gas in the Department of Industrial Ecology at the Royal Institute of Technology, Sweden, and received her $\mathrm{PhD}$ from the State Key Laboratory of Clean Energy Utilization at the Zhejiang University, China. Her research interests include biofilm and suspension microalgae cultivation for emission reduction and microalgae biomass utilization.

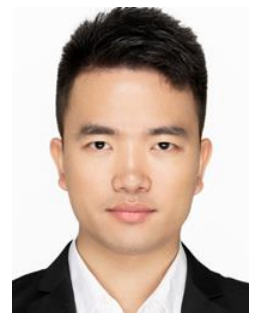

Dr. Xianqing Zhu is a lecturer at the School of Energy and Power Engineering, Chongqing University. He received his $\mathrm{PhD}$ from the School of Energy and Power Engineering at Huazhong University of Science and Technology in 2018. His research interests include thermal conversion of biomass, high efficiency recovery of spent lithiumion batteries, and CFD simulation of pyrolysis and gasification of organic solid waste.

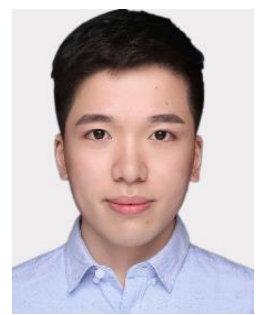

Cheng Chen is a postgraduate student at the Chongqing University. He received his bachelor degree from the School of Energy and Power Engineering at the Chongqing University. $\mathrm{He}$ is currently engaged in research on microbial energy conversion and utilization at the Institute of Engineering Thermophysics.

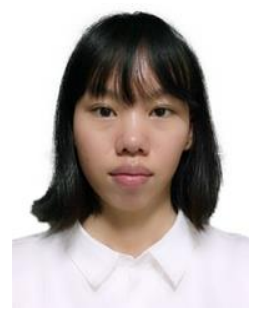

Wenfan Ye received her master degree from the School of Energy and Power Engineering at the Chongqing University. Her research is focused on new energy utilization technologies and systems at the Institute of Engineering Thermophysics. 